Pak. j. sci. ind. res. Ser. B: biol. sci. 201558 (2) 98-103

\title{
Distribution and Abundance of Marine Debris Along the Coast of Karachi (Arabian Sea), Pakistan
}

\author{
Rashida Qari* and Moniba Shaffat \\ Institute of Marine Science, University of Karachi, Karachi 75270, Pakistan \\ (received August 20, 2014; revised May 26, 2015; accepted June 4, 2015)
}

\begin{abstract}
This study reports the first assessment of distribution and abundance of marine debris along the coast of Karachi (Arabian Sea), Pakistan. The quadrate method was used for estimating the debris material. Total 40 quadrates were made for collecting the debris on 4 beaches: Sandspit, Buleji, Paradise Point and Korangi Creek in the year of 2012. Nine different types of debris comprising of plastics, glasses, thermopore, clothing, rubber, paper, pot pieces and cigarette filters were collected. The study revealed that, plastic was found in high quantity at all four beaches of Karachi. Other most common items were as follow: plastic at Paradise Point and Sandspit; pot pieces at Korangi Creek and rubber at Buleji. A total weight of $12277.45 \mathrm{~g}$ debris was recorded during the whole study period. It was also noted that Paradise Point is the dirtiest beach (5612.6 g) when compared with other studied beaches.
\end{abstract}

Keyword: marine pollution, beaches, debris, plastic, Pakistan

\section{Introduction}

Marine debris or marine litter is one of the global marine pollutions produced by human and released accidentally or deliberately in the ocean. Marine debris not only affects the marine organisms (animals and plants) and environment qualitatively but also hampers the commercial economy activities related to marine foods (e.g., fish). Many types of debris materials are released in the ocean. Cigarette filters, beverage bottles and cans, food wrappers, fishing line, nets and gear are some of the most common debris type that enter the ocean environment from any source (Coe and Rogers, 1997). Much of the debris reaches the ocean after people engaged in beach-going activities have discarded it. The debris is often blown into the water and other debris comes from activities in the water, including vessels, offshore drilling rigs and platforms and fishing piers.

Many forms of marine debris especially derelict fishing gear pose serious threats to wildlife. According to the U.S Marine Mammal Commission, 136 marine species have been reported in entanglement incidents, including six species of sea turtles, 51 species of seabird, and 32 species of marine mammals (Clark, 2008). Derelict fishing or ghost fishing gear also causes damage when abandoned fishing gear and nets continue to catch and kill ocean life. Discarded gear may cause significant

*Author for correspondence; E-mail: rqari2002@yahoo.com losses of some commercially valuable fish and crab species (Laist, 1997).

Major category of solid waste is plastic which is practically indestructible. According to Clark (2007) drift nets, especially monofilament gillnets do not catch the fish alone, but a large number of birds and sea mammals are also trapped by them and drown. Sea birds trapped by gillnets include the Laysan albatross (Diomedea immortabilis) Fulmarus (Fulmarus glacialis) Shear water (Pufinus griseus) and Tufted Puffins (Launda cirrhata).

Most of the studies regarding debris along the shoreline are focused on large, visible material found on beaches, with only a few studies describing abundance of material in the water column (Lattin et al., 2004). Mistaken ingestion of micro plastic occurs in seabirds, fish and various planktivores (Laist, 1997; Carpenter et al., 1972). Injection of plastic can have harmful effects, such as diminished food consump-tion, loss of nutrition, internal injury, intestinal blockage, starvation and death (Derraik, 2002; Redford et al., 1997). Plastic is a threat to humanity because plastic does not degrade readily but is only broken into small particles called microplastics, may accumulate in plankton consuming animals, and could be passed up in the food chain (Gago et al., 2014; Derraik, 2002). In addition, plastic pellets and fragments can transfer chemical pollutants to organisms (Derraik, 2002). Recently European Marine Strategy Framework Directive (MSFD) working group develop the monitoring guidance for marine litter 
in European Sea (Galgani et al., 2013b). It is an estimate that each year millions of tonnes of plastic enter the ocean (Edyvane et al., 2004). The present study is the first comprehensive attempt that deals with the density, distribution and composition with complete picture of marine debris on the coast of Karachi, Pakistan with basic aim to reduce pollution in the coastal areas and protection of marine environment.

\section{Materials and Methods}

A debris study was conducted in the month of August 2012 at low tide on 4 beaches (Sandspit, Buleji, Paradise Point and Korangi Creek), along the coast of Karachi during 2012 (Fig. 1). The sampling method of Chapman (1964) was used for estimating the debris presence and abundance. A quadrate frame made of wood (one-meter square) was employed. Ten replicates (ten feet apart) parallel to the coast line were randomly sampled in the intertidal belt horizontally at each beach. Debris falling inside each quadrate were taken and placed individually in prelabeled plastic bags and returned to the laboratory.

In the laboratory, each sample of debris was placed on a sheet of white paper and all samples of debris were sorted by category (plastic, glass, clothing, paper, thermopore, rubber, fishing nets, pot pieces and cigarette filters) placed in separate containers, and labeled with location and type. After sorting, each sample was weighed with a fine degree of accuracy (0.001 g). Subsequently, the total weight and mean of each debris type was calculated in ten quadrates at each site.

Beach characteristics. The site of Sandspit is situated south west of Karachi. It is rocky and white sandy area where many sandy pits have been found. The sea is very calm and quiet from October to March and very rough during the south west monsoon. Sandspit is quite

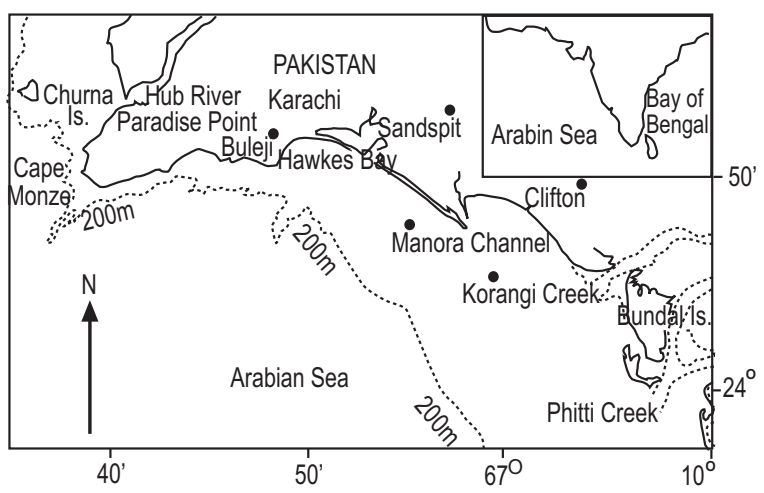

Fig. 1. Map of the Karachi Coast showing locations of the four beaches. popular picnic and recreational spot in Karachi. During south west monsoon, high tides often cross over and enter into the backwater mangrove area, and refurbish the sediments with coastal sand.

Buleji is the triangular rocky plate Island. It lies at $24^{\circ} 54 \mathrm{~N}$ and $66^{\circ} 48 \mathrm{E}$ of Karachi, between Hawks Bay and Paradise Point covering a distance of about 800 meters. The shore with small and large pools of water exposed at low tides. Boulders of various sizes are visible but mostly near the higher watermark standing on a rocky base or on sand, gravel, cobbles and pebbles etc. The middle and lower area of the ledge are made-up of rather flat continuous rocks and comparatively small boulders.

Paradise Point is also recreational beach. The coast is open to sea front and the wave action is intense all along the coast. The rocky ledge of Paradise Point is mostly wave swept shore (Qari and Siddiqui, 2010; 2005). The beach has attraction for families and tourists.

Korangi Creeks area is dominated by mangroves (Shahzad et al., 2009) and worst pollution affected, where the effluents from Korangi, Landhi, Karachi Export Processing Zone, Bin Qasim Industrial Area, and Pakistan Steel Mill are directly discharged into the sea. Untreated waste water from the industries is discharged into the fourth studied beach (Korangi Creek) through a poorly maintained drainage network (Abbas, 2006). In addition to industrial effluents, discharges from Bhains (buffalo) Colony cattle farms and domestic sewage from residential areas also end up in the Korangi Creek system.

\section{Results and Discussion}

The studied beaches: Sandspit, Buleji, Paradise Point and Korangi Creek of Karachi are highly polluted by manmade debris. There is much variation observed in numbers and weight of debris items throughout the coastal belt of studied beaches of Karachi coast. Nine different types of debris items (plastic, glass, clothing, paper, thermopore, rubber, fishing nets, pot pieces and cigarette filters) were identified throughout the study period (Fig. 2). The weight, composition and use of each debris item are described in Table 1. A great variation was found in debris items and their weight that were collected from 10 quadrates at 4 different coastal areas of Karachi coast: Sandspit, Buleji, Paradise Point and Korangi Creek (Fig. 3A-D). The total weight of debris collected at all beaches was $12278.05 \mathrm{~g}$. The highest quantity of debris was found at Paradise Point (5612.6 g) as compared to Sandspit (140.65 g), Buleji (3944.8 g) and Korangi Creek (2580 g) (Fig. 4). Paradise 


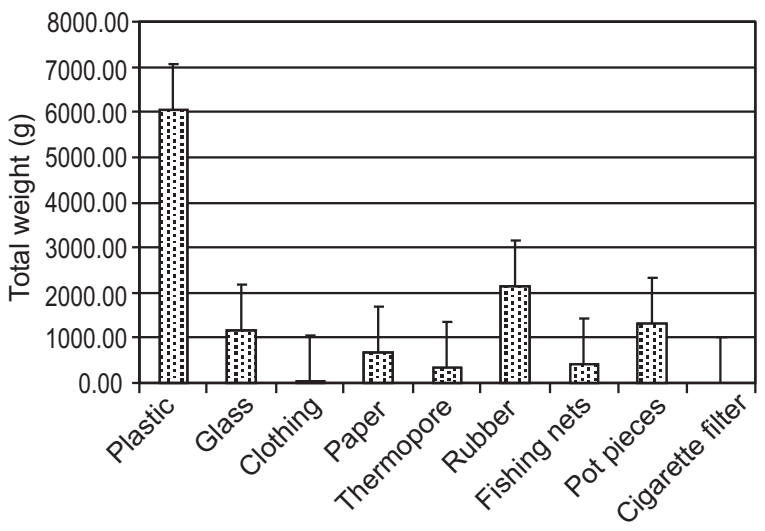

Fig. 2. Total weight of different debris material found at Karachi coast (Bars represent standard error of the mean).

Point was found to be the most polluted coast $(5612.6 \mathrm{~g}$ ) and the less polluted coast with $140.65 \mathrm{~g}$ debris was Sandspit (Fig. 3AC and Fig. 4).

The present study revealed that plastic is the dominant debris $(49.43 \%)$ as compared to other debris items (Fig. 2). The plastic debris was abundantly found at all four studied beaches; Sandspit ( $\left.7.57 \mathrm{~g} / \mathrm{m}^{2}\right)$, Buleji (104.5 $\left.\mathrm{g} / \mathrm{m}^{2}\right)$, Paradise Point $\left(507.76 \mathrm{~g} / \mathrm{m}^{2}\right)$ and Korangi creek $\left(11.54 \mathrm{~g} / \mathrm{m}^{2}\right)$ of Karachi coast (Fig. 3). The total plastic debris weight found at all 4 studied beaches of Karachi coast was $6070.17 \mathrm{~g}$ in the whole study period (Table 1). Plastic debris contained small and large bags, juice boxes, container bottles and packing materials. It was also observed that at Paradise Point the highest amount of plastic was found (90.46\%). Paradise Point showed the greatest number of small plastic bags. There was above 60 pieces of different food products counted in each quadrate at the beach of Paradise Point.

Rubber debris (17.67\%) consisted of only shoes. It was at Buleji $402.8 \mathrm{~g} / \mathrm{m}^{2}$ and at Paradise Point $155.6 \mathrm{~g} / \mathrm{m}^{2}$ (Fig. $3 \mathrm{~A}$ and D). It was not found at Korangi Creek and Sandspit. The pot pieces $(10.74 \%)$ were found only at Sandspit $\left(26.5 \mathrm{~g} / \mathrm{m}^{2}\right)$ and Korangi Creek $\left(184.57 \mathrm{~g} / \mathrm{m}^{2}\right)$, respectively (Fig. $3 \mathrm{~A}$ and D). Glass $(9.72 \%$ ) was found only at two beaches, Sandspit $\left(7.76 \mathrm{~g} / \mathrm{m}^{2}\right)$ and Korangi Creek ( $\left.148.3 \mathrm{~g} / \mathrm{m}^{2}\right)$ as shown in Fig 3 A and D. Glass was the second highest at Korangi Creek (Fig. 3 D). Paper debris was $5.54 \%$ of total debris, composed of juice boxes, newspapers and wrappers of burgers and other food items. Paper debris was found only at Buleji $\left(81.25 \mathrm{~g} / \mathrm{m}^{2}\right)$ and Paradise Point $\left(71.0 \mathrm{~g} / \mathrm{m}^{2}\right)$ beach (Fig. $3 \mathrm{~B}$ and C). Total weight of paper collected from these two beaches was $680.80 \mathrm{~g}$ (Table 1 and Fig. 2).
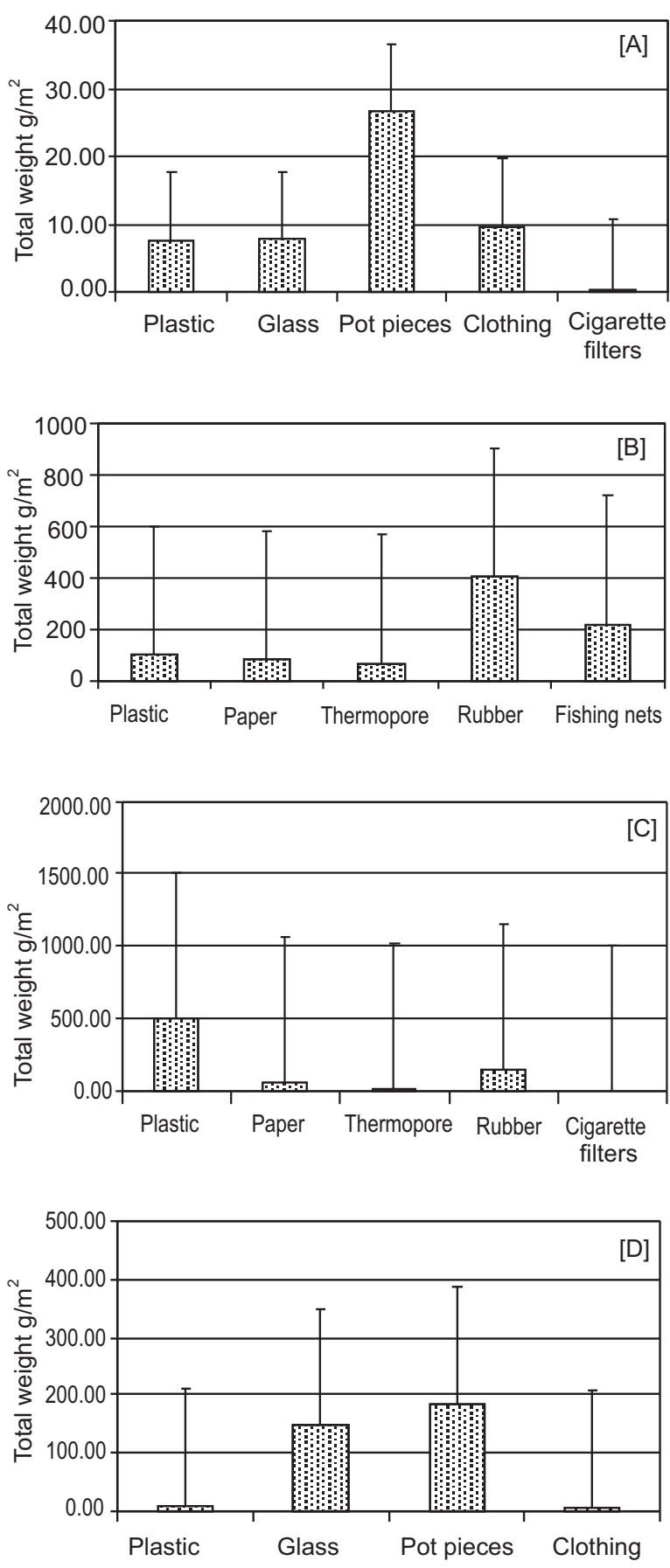

Fig. 3. Total debris material collected at the Karachi coast: (A) Sandspit, (B) Buleji, (C) Paradise Point, (D) Korangi Creek (Bars represent standard error of the mean).

Fishing nets (3.56 \%) were found only at Buleji (218.8 $\mathrm{g} / \mathrm{m}^{2}$ ) because Buleji is a coast used for fishing (Fig. 3 B). Thermopore or packing material was $2.86 \%$ of total debris and it was found only at Buleji $\left(66.2 \mathrm{~g} / \mathrm{m}^{2}\right)$ and Paradise 
Table 1. Total weight of debris items collected from different beaches of Karachi coast

\begin{tabular}{|c|c|c|c|c|c|}
\hline S.No & Type of debris & Sampling beach & Total weight (g) & Composition & Use \\
\hline 1 & Plastic & $\begin{array}{l}\text { Sandspit } \\
\text { Buleji } \\
\text { Paradise Point } \\
\text { Korangi Creek } \\
\text { Total }\end{array}$ & $\begin{array}{l}75.77 \\
836.00 \\
5077.6 \\
80.80 \\
6070.17\end{array}$ & $\begin{array}{l}\text { Organic polymers } \\
\text { (Polystyrene, Polyvinyl } \\
\text { Chloride) }\end{array}$ & $\begin{array}{l}\text { Bags for food items } \\
\text { and packing }\end{array}$ \\
\hline 2 & Glass & $\begin{array}{l}\text { Sandspit } \\
\text { Korangi Creek } \\
\text { Total }\end{array}$ & $\begin{array}{l}7.76 \\
1186.4 \\
1194.16\end{array}$ & $\begin{array}{l}\text { Silica, potassium, } \\
\text { alumina, sodium, } \\
\text { magnesium, calcium }\end{array}$ & $\begin{array}{l}\text { In building windows } \\
\text { and making } \\
\text { cutlery }\end{array}$ \\
\hline 3 & Pot pieces & $\begin{array}{l}\text { Sandspit } \\
\text { Korangi Creek } \\
\text { Total }\end{array}$ & $\begin{array}{l}26.50 \\
1292.8 \\
1319.30\end{array}$ & Clay & Decoration purposes \\
\hline 4 & Clothing & $\begin{array}{l}\text { Sandspit } \\
\text { Korangi Creek } \\
\text { Total }\end{array}$ & $\begin{array}{l}28.82 \\
20.00 \\
48.82\end{array}$ & Cotton & Cloth \\
\hline 5 & Paper & $\begin{array}{l}\text { Buleji } \\
\text { Paradise point } \\
\text { Total }\end{array}$ & $\begin{array}{l}325.60 \\
355.20 \\
680.8\end{array}$ & $\begin{array}{l}\text { Cellulose, hemi } \\
\text { cellulose, lignin }\end{array}$ & $\begin{array}{l}\text { Writing, roofing, } \\
\text { flooring }\end{array}$ \\
\hline 6 & Thermopore & $\begin{array}{l}\text { Buleji } \\
\text { Paradise point } \\
\text { Total }\end{array}$ & $\begin{array}{l}331.60 \\
20.40 \\
352\end{array}$ & Polystyrene & $\begin{array}{l}\text { For insulation and } \\
\text { packing }\end{array}$ \\
\hline 7 & Rubber & $\begin{array}{l}\text { Buleji } \\
\text { Paradise point } \\
\text { Total }\end{array}$ & $\begin{array}{l}2014 \\
155.60 \\
1319.30\end{array}$ & $\begin{array}{l}\text { Polybutadiene, } \\
\text { Polystyrene and } \\
\text { Natural rubber }\end{array}$ & $\begin{array}{l}\text { Slippers, rubber band, } \\
\text { holding and tighting } \\
\text { purposes }\end{array}$ \\
\hline 8 & Fishing nets & $\begin{array}{l}\text { Buleji } \\
\text { Total }\end{array}$ & $\begin{array}{l}437.60 \\
437.60\end{array}$ & (Polyisoprene) thread & for catching fish \\
\hline 9 & Cigarette filters & $\begin{array}{l}\text { Sandspit } \\
\text { Paradise point } \\
\text { Total }\end{array}$ & $\begin{array}{l}1.8 \\
3.8 \\
5.6\end{array}$ & Cellulose acetate & Smoking \\
\hline
\end{tabular}

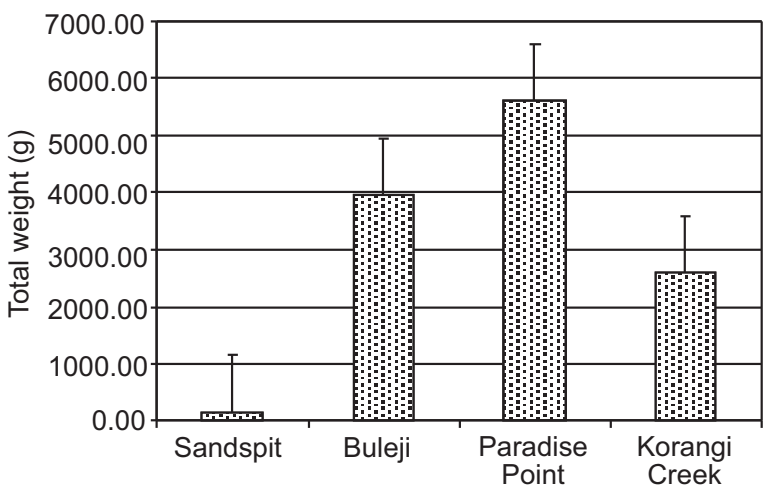

Fig. 4. Total debris material at different sites of Karachi coast (Bars represent standard error of the mean).

point $\left(10.02 \mathrm{~g} / \mathrm{m}^{2}\right)$ (Fig. $3 \mathrm{~B}$ and C). The debris item clothing $(0.39 \%)$ was found only at Sandspit $\left(9.6 \mathrm{~g} / \mathrm{m}^{2}\right)$ and Korangi Creek $\left(6.67 \mathrm{~g} / \mathrm{m}^{2}\right)$ (Fig. $3 \mathrm{~A}$ and D). Cigarette filters $(0.04 \%)$ were found at two locations Sandspit ( 0.45 $\left.\mathrm{g} / \mathrm{m}^{2}\right)$ and Paradise Point $\left(1.27 \mathrm{~g} / \mathrm{m}^{2}\right)$ (Fig. $3 \mathrm{~A}$ and C), both of these beaches are picnic point.

The data of debris items at different coasts were analysed by looking at the relationship between different coasts and debris items. There was no particular correlation found in between type of debris studied at different coasts except Sandspit and Paradise Point debris showed positive significant correlation $\left(r^{2}=0.930\right)$. Most of the types of debris showed positive significant correlation: plastic and cigarette filters $\left(r^{2}=0.838\right)$, plastic and paper $\left(r^{2}=0.735\right)$, glass and pot pieces $\left(\mathrm{r}^{2}=1.000\right)$, paper and thermopore $\left(r^{2}=0.575\right)$, paper and rubber $\left(r^{2}=0.588\right)$, paper and fishing nets $\left(r^{2}=0.526\right)$, thermopore and rubber $\left(r^{2}=\right.$ 1.000), thermopore and fishing nets $\left(\mathrm{r}^{2}=0.998\right)$ and fishing nets and rubber $\left(\mathrm{r}^{2}=0.997\right)$, clothing and rubber $\left(\mathrm{r}^{2}=0.735\right)$, pot pieces and fishing net $\left(r^{2}=0.762\right)$ thermopore and clothing $\left(r^{2}=741\right)$. 
From the observation of debris items it has been noted that, sources of most of the debris are human activities. The plastic items (49.43\%) were the most abundant marine debris type in the whole study period (Fig. 5), followed by rubber (17.67\%), pot pieces (10.74\%) and glass (9.72\%). The present results are similar with the results of study conducted at the beaches of northern New South Wales, Australia (Taffs and Cullen, 2005). Similar results were also observed by Lazar and Gracan (2011) when they studied the occurrence and impacts of marine debris ingestion by logger head sea turtles, Carette caretta in the foraging habitats of the eastern Adriatic Sea, recorded 35.2\% turtles eaten marine litter with plastic dominant. In the present study, majority of plastic debris consists of bags in addition to other items of plastic that were abundantly found at all studied beaches. The possible reason could be the use of plastic in our modern life. Plastic is an environmental hazard as it does not break down easily in the environment and its presence in various forms causes harm to marine life. Harmful effects from the ingestion of plastics include blockage of gastric enzyme secretion, diminished feeding stimulus, lowered steroid hormone levels, delayed ovulation and reproduction failure (Derraik, 2002). Gago et al. (2014) also reported that, most common element found in beach litter was made of plastic with average percent of 63,38 and 83 when a seasonal series of sampling was conducted on three beaches of Galician coast, Spain for the assessment of the situation of beach litter. The ingestion of plastic debris by small fish and seabirds for instance, can reduce food uptake, cause internal injury and death following blockage of intestinal tract (Derraik, 2002; Ryan, 1987). The issue of plastic connects to several European water policies for the good environmental status of marine waters (Galgani et al., 2013a)

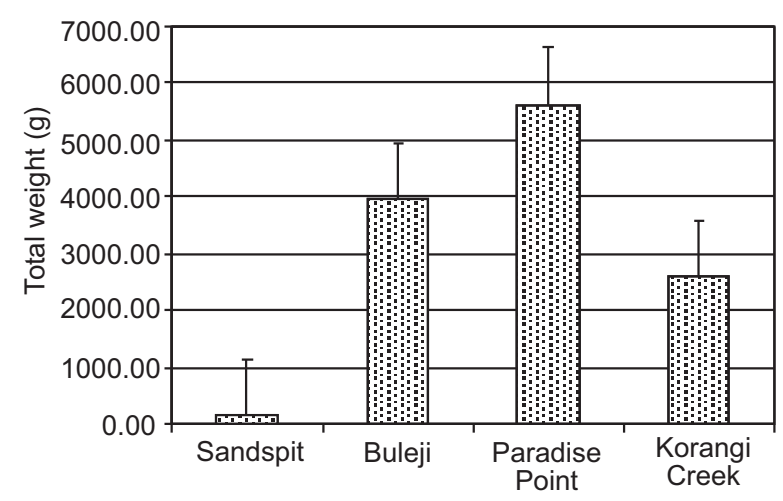

Fig. 5. Total plastic debris material at different sites of Karachi coast (Bars represent standard error of the mean).

\section{Conclusion}

It is concluded that the present study provide baseline data on density, distribution and composition of manmade debris at different beaches of Karachi. It is also concluded that the management of beaches needs to be focused on reducing the debris or litter especially plastic pollution entering the marine environment from different sources. It is also assumed that plastic is major threat to marine mammals, turtles and birds through entrapment and digestion. It is very necessary to display restriction on all the beaches of Karachi for all kinds of debris especially plastic. The trash containers should be fixed for all debris like pieces of fishing line, net or other litter along the coast. The debris material should be reduced, reused and recycled. It is also necessary to place all trash on ship or boat for proper disposal on land and at the beach. People should take trash home with them when they return from picnics. Public awareness programmes should be under taken to keep the beaches clean.

\section{References}

Abbas, Q. 2006. The Influence of Oil Spill by Tasman Spirit on the Chemical and Biochemical Composition of Seaweeds around the Coast of Karachi. M.Phil Thesis, 139 pp., University of Karachi, Pakistan.

Carpenter, E.J., Anderson, S.J., Harvey, G.R., Miklas, H.P., Peck, B.B. 1972. Polystrene spherules in coastal waters. Science, 178: 749-750.

Chapman, V.J. 1964. Coastal Vegetation. 256 pp., Pergamon Press, Oxford, UK.

Clark, R.B. 2008. Marine Pollution, 237 pp., $5^{\text {th }}$ edition, Oxford University Press, Oxford, UK.

Coe, J.M., Rogers, D.B. 1997. Marine Debris - Sources, Impacts and Solutions. pp. 141-151, SpringerVerlag, New York, USA.

Derraik, J.G.B. 2002. The pollution of the marine environment by plastic debris: a review. Marine Pollution Bulletin, 44: 842-852.

Edyvane, K.S., Dalgetty, A., Hone, P.W., Higham, J.S., Wace, N.M. 2004. Long term marine litter monitoring in the remote Great Australian Bight, South Australia. Marine Pollution Bulletin, 48: 10601075 .

Gago, J., Lahuerta, F., Antelo, P. 2014. Characteristics (abundance, type and origin) of beach litter on the Galician coast (NW Spain) from 2001 to 2010. Scientia Marine, 78: 1-10.

Galgani, F., Hanke, G., Werner, S. and De Vrees, L. 2013a. Marine litter within the European Marine 
Strategy Framework Directive. ICES Journal of Marine Science, 70: 1055-1064.

Galgani, F., Hanke, G., Werner, S., Oosterbaan, L., Nilsson, P., Fleet, D., Kinsey, S., Thompson, R. C., Van Franeker, J., Vlachogianni, T., Scoullos, M., Mira, Veigo J., Palatinus, A., Matiddi, M., Maes, J., Korpinen, S., Budziak, A., Leslie, H., Gago, J., Liebezeit, G. 2013b. Guidance on monitoring of marine litter in European Seas. MSFD Technical Subgroup on Marine Litter (TSG-ML). Laist, D.W. 1997. Impacts of marine debris: entanglement of marine life in marine debris including a comprehensive list of species with entanglement and ingestion records. In: Marine Debris - Sources, Impacts and Solutions. J.M. Coe and D.B. Rogers, (eds.), pp. 99143, Springer-Verlag, New York, USA.

Lattin, G.L., Moore, C.J., Zellers, A.F., Moore, S.L., Weisberg, S.B. 2004. A comparison of neustonic plastic and zooplankton at different depths near the southern California shore. Marine Pollution Bulletin, 49: 291-294.

Lazar B., Gracan, R. 2011. Ingestion of marine debris by loggerhead sea turtles, Caretta caretta, in the Adriatic Sea. Marine Pollution Bulletin, 62: 43-47.
Qari, R., Siddiqui, S.A. 2010. A comparative study of heavy metal concentrations in red seaweeds from different coastal areas of Karachi, Arabian Sea. Indian Journal of Geo-Marine Science, 39: 27-42.

Qari, R., Siddiqui S.A. 2005. Variations of heavy metals in green seaweeds from Karachi coast of Pakistan. Pakistan Journal of Scientific and Industrial Research, 48: 195-201.

Ryan, P.G. 1987. The effects of ingested plastic on seabirds: correlations between plastic load and body condition. Environmental Pollution, 46: 119-125.

Redford, D.P., Trulli, H., Trulli, W. 1997. Sources of plastic pellets in the aquatic environment. In: Marine Debris: Sources, Impacts, and Solutions. J.M. Coe and D.B. Rogers (eds.), pp. 335-343, SpringerVerlag, New York, USA.

Shahzad, A.,Moazzam, A., Shoukat, S., Ahmad, W. 2009. Chemical pollution profile of Rehri Creek Area, Karachi (Sindh). Journal of Chemical Society, 31: 592-600.

Taffs, K.H., Cullen, M.C. 2005. The distribution and abundance of marine debris on isolated beaches of northern New South Wales, Australia. Australian Journal of Environmental Management, 12: 244-250. 